\title{
Association Between Dialysate Sodium Concentration And Interdialytic Weight Gain In Patients Undergoing Twice Weekly Haemodialysis
}

\section{Soraiya Manji}

Aga Khan University

Jasmit Shah

Aga Khan University

Ahmed Twahir

Aga Khan University

Ahmed Sokwala ( $\square$ ahmed.sokwala@aku.edu )

Aga Khan University

\section{Research Article}

Keywords: Dialysate sodium concentration, interdialytic weight gain, blood pressure

Posted Date: December 28th, 2020

DOI: https://doi.org/10.21203/rs.3.rs-131271/v1

License: @ (i) This work is licensed under a Creative Commons Attribution 4.0 International License.

Read Full License 


\section{Abstract}

\section{Background}

Chronic kidney disease is highly prevalent across the globe with more than two million people worldwide requiring renal replacement therapy. Interdialytic weight gain is the change in body weight between two sessions of haemodialysis. Higher interdialytic weight gain has been associated with an increase in mortality and adverse cardiovascular outcomes. It has long been questioned whether using a lower dialysate sodium concentration during dialysis would reduce the interdialytic weight gain and hence prevent these adverse outcomes.

Methods

This study was a single blinded cross-over study of patients undergoing twice weekly haemodialysis at the Aga Khan University Hospital, Nairobi and Parklands Kidney Centre. It was conducted over a twelveweek period and patients were divided into two groups: dialysate sodium concentration of $137 \mathrm{meq} / \mathrm{l}$ and $140 \mathrm{meq} / \mathrm{l}$. These groups switched over after a six-week period without a washout period. Univariate analysis was conducted using Fisher's exact test for categorical data and Mann Whitney test for continuous data.

Results

41 patients were included in the analysis. The mean age was 61.37 years, and $73 \%$ were males. The mean duration for dialysis was 2.53 years. The interdialytic weight gain was not significantly different between the two groups (2.14 for the $137 \mathrm{meq} / \mathrm{I}$ group and 2.35 for the $140 \mathrm{meq} / \mathrm{I}$ group, $p=0.970$ ). Mean blood pressures were as follows: pre-dialysis: DNa 137meq/l: systolic $152.14 \pm 19.99$, diastolic $78.99 \pm$ 12.20, DNa 140meq/l: systolic $156.95 \pm 26.45$, diastolic $79.75 \pm 11.25$ ( $p=0.379,0.629$ respectively). Post-dialysis: DNa 137meq/l: systolic $147.29 \pm 22.22$, diastolic $77.85 \pm 12.82 \mathrm{DNa} 140 \mathrm{meq} / \mathrm{l}$ : systolic $151.48 \pm 25.65$, diastolic $79.66 \pm 15.78$ ( $p=0.569,0.621$ respectively) .

Conclusion

There was no significant difference in the interdialytic weight gain as well as pre dialysis and post dialysis systolic and diastolic blood pressures between the two groups. Therefore, using a lower dialysate sodium concentration does not appear useful in altering the interdialytic weight gain although further studies with a larger sample size are warranted.

\section{Background}

Chronic kidney disease (CKD) is the presence of kidney damage or decreased kidney function for three or more months, irrespective of the cause. Globally CKD has a prevalence of $13.4 \%$, with $10.6 \%$ being in stage 3-5 of the Kidney Disease Improving Global Outcomes (KDIGO) classification of CKD between the year 2000 to 2014 (1). The mortality rate for patients with CKD globally is also high, particularly for those 
on renal replacement therapy (2). More than two million people globally are requiring renal replacement therapy. However, there is less renal replacement therapy in the developing world due to lack of access and affordability issue (3). This has resulted in patients with End Stage Renal Disease (ESRD) having less than the recommended number of sessions of dialysis. The current recommendations as per the Kenya Disease Outcomes Quality Initiative (KDOQI) guidelines for haemodialysis adequacy are geared towards more frequent and shorter duration of dialysis (4). Unfortunately, this is far from the case in subSaharan Africa (SSA). In a study done at Kenyatta National Hospital in Kenya, $98.15 \%$ of patients underwent haemodialysis less than three times a week (5). The health insurance scheme in Kenya (National Health Insurance Fund - NHIF) covers two sessions of dialysis per week, and those getting three or more sessions per week have to cover the cost of dialysis themselves, which poses a great challenge as far as moving towards reduced morbidity and mortality from ESRD (6).

Usually, the operator of the dialysis machine (nurse) must set the dialysate concentration for the dialysis session. During the process of dialysis, sodium is lost from the blood by ultrafiltration into the dialysate fluid. The dialysate sodium concentration therefore has to be lower than the serum sodium so as to allow diffusion to occur and the serum sodium to be lowered (dialysate sodium at least 2 meq/l lower than serum sodium). Using a higher dialysate sodium concentration results in 'sodium-loading' and thus activates the centre of thirst in the hypothalamus which makes the patient drink more water with subsequent weight gain and volume expansion. There is also an increase in sympathetic tone and release of vasopressin which may result in increased blood pressure and cardiovascular sequelae (7).

Interdialytic weight gain is 'the change in body weight between two sessions of haemodialysis (8). With time, the set dialysate sodium concentration has gradually evolved from $126.5 \mathrm{meq} / \mathrm{l}$ in the $1940 \mathrm{~s}$, to around $140 \mathrm{meq} / \mathrm{l}$ in the 1990s, but there is no consensus on the optimal dialysate sodium concentration (7). There has been conflicting evidence, but many studies suggest that with a higher dialysate sodium there is a higher interdialytic weight gain and higher blood pressures. There has also been a trend towards increased mortality, heart failure and major cardiac events (nonfatal myocardial infarction, nonfatal ischemic stroke, or cardiovascular death) as well as hospitalisations in patients with a higher interdialytic weight gain (9)(10).

Therefore, the aim of this study was to determine if dialysate sodium concentration has any bearing on interdialytic weight gain and blood pressure control. Most studies that have been done are observational with very few clinical trials. Furthermore, in most centres where these studies were done, patients were undergoing thrice weekly dialysis. In our set-up, majority of our patients undergo twice weekly dialysis, which would predispose them to a higher interdialytic weight gain due to a longer duration between dialysis sessions.

\section{Methods}

\section{Study aim}


The primary objective was to determine the association between the dialysate sodium concentration and interdialytic weight gain in patients undergoing haemodialysis twice weekly. The secondary objective was to determine the relationship between dialysate sodium concentration and blood pressure in patients undergoing haemodialysis twice weekly.

\section{Study setting}

The study setting was the Aga Khan University Hospital dialysis unit and Parklands Kidney Centre. The Aga Khan University Hospital is a private, not-for-profit teaching hospital and the dialysis unit at the hospital has 9 dialysis machines, with approximately 18 patients undergoing dialysis every day. There are approximately 48 patients in total on dialysis at the unit, out of which 30 are on twice-weekly dialysis. Parklands Kidney Centre is an outpatient dialysis unit that has 19 dialysis machines and approximately 90 patients in total, out of which approximately 45 are on twice-weekly dialysis.

\section{Study design and subjects}

The study was a randomized single blind crossover study design. Each group was dialysed using a dialysate sodium of 140 and $137 \mathrm{meq} / \mathrm{l}$ at different time periods. The study was conducted at the Aga Khan University Hospital dialysis unit and Parklands Kidney Centre dialysis unit in Nairobi, Kenya on patients undergoing twice weekly dialysis over a period of 12 weeks.

The inclusion criteria was as follows: age greater than 18 years, patients undergoing dialysis twice a week, patients who consented to be a part of the study. The exclusion criteria was as follows: patients with blood pressures less than 100/60, hospital in-patients. Withdrawal criteria was as follows: patients who develop intradialytic hypotension (reduction in systolic blood pressure of $20 \mathrm{mmHg}$ or a reduction in MAP of $10 \mathrm{mmHg}$ accompanied by symptoms such as muscle cramps, abdominal discomfort, dizziness, nausea, vomiting, yawning, sighing, restlessness, or anxiety).

Figure 1 shows the study flow. The first group of patients were dialysed using a DNa of $140 \mathrm{meq} / \mathrm{l}$ for six weeks, followed by $137 \mathrm{meq} / \mathrm{l}$ for the remaining six weeks. The second group were dialysed using a DNa of $137 \mathrm{meq} / \mathrm{l}$ for six weeks, followed by $140 \mathrm{meq} / \mathrm{l}$ for the remaining six weeks. A total of 41 patients were included in the analysis.

\section{Statistical analysis}

Categorical data were presented as frequencies and percentages whereas continuous data were presented as means and standard deviations. Univariate analysis was conducted using Fisher's exact test for categorical data and Mann Whitney test for continuous data. The comparison between IDWG and mean systolic and diastolic blood pressure with each sodium group chosen for this study was conducted using the mean IDWG and mean systolic/diastolic blood pressure using Mann Whitney test.

\section{Results}




\section{Demographic and clinical characteristics}

The mean age of participants was 61.39 (SD=13.82) with a predominantly male population $(73 \%)$. The most common cause of CKD in these patients was hypertension, followed by diabetes mellitus. Most patients were oliguric. $59 \%$ of patients had a fistula for dialysis access, whereas the remainder had internal jugular permanent dialysis catheters. Only $45 \%$ of patients were on diuretics. The mean number of years of the patients on dialysis was 2.53. Table 1 shows the demographic and clinical characteristics.

\begin{tabular}{|c|c|c|}
\hline \multicolumn{2}{|l|}{ Age (years) } & $61.39 \pm 13.82$ \\
\hline \multirow[t]{2}{*}{ Gender } & Female & $11(27 \%)$ \\
\hline & Male & $30(73 \%)$ \\
\hline \multicolumn{3}{|c|}{ Cause of ESRD ( $\mathrm{n}(\%)$ ) } \\
\hline \multicolumn{2}{|c|}{ Diabetes Mellitus } & $24(59 \%)$ \\
\hline \multicolumn{2}{|l|}{ Hypertension } & $33(80 \%)$ \\
\hline \multicolumn{2}{|l|}{ HIV } & $3(7 \%)$ \\
\hline \multicolumn{2}{|c|}{ Glomerulonephritis } & $3(7 \%)$ \\
\hline \multicolumn{2}{|c|}{ Multiple Myeloma } & $1(2 \%)$ \\
\hline \multicolumn{2}{|c|}{ Contrast Induced Nephropathy } & $1(2 \%)$ \\
\hline \multicolumn{2}{|c|}{ Obstructive Uropathy } & $1(2 \%)$ \\
\hline \multicolumn{2}{|c|}{ Non-Steroidal Anti Inflammatory Drugs } & $2(5 \%)$ \\
\hline \multirow[t]{3}{*}{ Urine Output } & Anuric & $5(13 \%)$ \\
\hline & Non-oliguric & $12(31 \%)$ \\
\hline & Oliguric & $22(56 \%)$ \\
\hline \multirow[t]{2}{*}{ Dialysis Access } & Fistula & $24(59 \%)$ \\
\hline & Permanent Catheter & $17(41 \%)$ \\
\hline \multirow[t]{2}{*}{ Diuretic Use } & No & $21(55 \%)$ \\
\hline & Yes & $17(45 \%)$ \\
\hline \multicolumn{2}{|c|}{ No. of years on dialysis } & $2.53 \pm 1.96$ \\
\hline
\end{tabular}

Table 1: Demographic and clinical characteristics of study participants Interdialytic weight gain 
The primary outcome was the interdialytic weight gain between the two groups of dialysate sodium. The average interdialytic weight gain was $2.14 \mathrm{~kg}$ in the low dialysate sodium group (DNa 137meq) and 2.35 in the high dialysate sodium group (DNa 140meq), with a p value of 0.970 , as seen in Table 2 and Figure 2.

\begin{tabular}{|c|c|c|c|c|c|}
\hline & $\begin{array}{l}\text { Low DNa } \\
\text { Na: 137) }\end{array}$ & (dialysate & $\begin{array}{l}\text { High DNa } \\
\text { Na: 140) }\end{array}$ & (dialysate & $\begin{array}{l}\mathrm{P} \\
\text { Value }\end{array}$ \\
\hline $\begin{array}{l}\text { Previous Post Dialysis } \\
\text { Weight }(\mathrm{kg})\end{array}$ & $72.27 \pm 16.77$ & & $72.24 \pm 16.69$ & & 0.948 \\
\hline Pre Dialysis Weight $(\mathrm{kg})$ & $75.20 \pm 17.23$ & & $74.37 \pm 17.02$ & & 0.856 \\
\hline IDWG (kg) & $2.14 \pm 1.10$ & & $2.35 \pm 1.38$ & & 0.970 \\
\hline
\end{tabular}

Table 2: Interdialytic weight gain between DNa 137meq/I and DNa 140meq/I

\section{Blood pressure}

The mean pre-dialysis systolic blood pressure was 151.54 in the low DNa group and 156.05 in the high DNa group, while the mean pre-dialysis diastolic blood pressure was 79.52 in the low DNa group and 80.81 in the high DNa group. The average post-dialysis systolic blood pressure was 147.6 in the low DNa group and 151.53 in the high DNa group, while the average post-dialysis diastolic blood pressure was 78.38 in the low DNa group and 80 in the high DNa group. None of these differences were statistically significant between both groups as shown in Table 3.

\begin{tabular}{|c|c|c|c|}
\hline & $\begin{array}{l}\text { Low DNa } \\
\text { Na: 137) }\end{array}$ & $\begin{array}{l}\text { High DNa } \\
\text { Na: 140) }\end{array}$ & $\begin{array}{l}\mathrm{P} \\
\text { Value }\end{array}$ \\
\hline $\begin{array}{l}\text { Pre-dialysis SBP } \\
(\mathrm{mmHg})\end{array}$ & $152.14 \pm 19.99$ & $156.95 \pm 26.45$ & 0.379 \\
\hline $\begin{array}{l}\text { Pre-dialysis DBP } \\
(\mathrm{mmHg})\end{array}$ & $78.99 \pm 12.20$ & $79.75 \pm 11.25$ & 0.629 \\
\hline $\begin{array}{l}\text { Post-dialysis SBP } \\
(\mathrm{mmHg})\end{array}$ & $147.29 \pm 22.22$ & $151.48 \pm 25.65$ & 0.569 \\
\hline $\begin{array}{l}\text { Post-dialysis DBP } \\
\text { (mmHg) }\end{array}$ & $77.85 \pm 12.82$ & $79.66 \pm 15.78$ & 0.621 \\
\hline
\end{tabular}

Table 3: Pre-dialysis and post-dialysis systolic and diastolic blood pressures between the two groups

\section{Adverse effects}

Of the 41 patients, two patients experienced hypotensive episodes. The first patient had asymptomatic hypotensive episodes on their $8^{\text {th }}$ and $12^{\text {th }}$ sessions of dialysis at dialysate sodium concentration of 140 
$\mathrm{meq} / \mathrm{l}$. The second patient developed an asymptomatic hypotensive episode in the $4^{\text {th }}$ session of dialysis at dialysate sodium concentration of $137 \mathrm{meq} / \mathrm{l}$ and a hypotensive episode on the $2^{\text {nd }}$ session of dialysis at dialysate sodium concentration $140 \mathrm{meq} / \mathrm{I}$. The latter required disconnection of the dialysis machine 30 minutes prior to completion. None of these episodes required saline infusion.

\section{Discussion}

This study has established that there is no association between dialysate sodium concentration and interdialytic weight gain. Furthermore, there was no association between dialysate sodium concentration and blood pressure. This was similar to what was found by Beduschi et al when comparing DNas of 135 and $138 \mathrm{meq} / \mathrm{l}$ where there was no significant difference in the interdialytic weight gain or the blood pressure (11). This was also the case in the study by Thein et al where there was no significant difference in the interdialytic weight gain between dialysate sodiums of 141 and $138 \mathrm{meq} / \mathrm{l}$, however there was a significant reduction in blood pressure with the lower dialysate sodium used (12). As much as there was no statistical significance in the interdialytic weight gain and blood pressure between the two groups, there could still be clinical significance as both parameters were lower in the lower dialysate sodium group.

It is important to note that there was no exclusion of patients with residual renal function in this study, yet residual renal function (defined as urine output of greater than $200 \mathrm{ml} /$ day) theoretically has a physiologic role in sodium balance (13). Ipema et al established that patients with residual diuresis had significantly lower interdialytic weight gain (14). However in terms of outcomes, Hecking et al noted no difference in mortality in patients with or without residual renal function in spite of the dialysate sodium concentrations used (10). In the present study, there was no difference in the outcomes in patients with or without residual renal function.

It has also been established in some studies such as that by Titze et al that large amounts of sodium can be accumulated without water retention by the sodium ions binding to extracellular matrix components such as glycosaminoglycans (15). In addition, there are other sodium reservoirs in the body such as the bone, skin cartilage and connective tissue and as a result, lowering the dialysate sodium concentration could have caused loss of sodium without loss of water and had no impact on the interdialytic weight gain and blood pressure (11).

There is also theory that every individual has their own individual osmolar setpoint based on parameters such as dietary salt intake, urinary sodium excretion, tissue sodium stores as well as physiologic response of the body to sodium. For this reason, a change in the dialysate sodium concentration may not have that much of an impact on the interdialytic weight gain and blood pressures unless the sodium level is individualised. This was shown in a study conducted by Radhakrishnan et al where they compared a set dialysate sodium concentration of $140 \mathrm{meq} / \mathrm{l}$ to an individualised dialysate sodium concentration. There was a significantly lower interdialytic weight gain and pre-dialysis systolic blood pressure in those 
patients who had an individualised dialysate sodium concentration in comparison to the standard dialysate sodium concentration of $140 \mathrm{meq} / \mathrm{l}(16)$.

This study showed no significant difference between the systolic or diastolic blood pressure in both dialysate sodium concentration groups. Charra et al described the concept of 'lag time', whereby it takes several months for the correction of the extracellular volume overload (in our case from the high sodium) to manifest as improvement in blood pressure (18). This study was 12 weeks long and therefore patients may not have completed this lag time.

An important finding on the study was the average interdialytic weight gain regardless of the dialysate sodium concentration used. The mean interdialytic weight gain was $2.14 \mathrm{~kg}$ and $2.35 \mathrm{~kg}$ for dialysate sodium $137 \mathrm{meq} / \mathrm{I}$ and $140 \mathrm{meq} / \mathrm{I}$ respectively. Comparing to other studies, for instance the PanThames renal audit done by Davenport et al undergoing dialysis three times a week showed an interdialytic weight gain range of 1.7 to $2.75 \mathrm{~kg}$ (9). Therefore, interdialytic weight gain in the this study is comparable to the interdialytic weight gains in the audit, despite the fact that our patient population was on twice weekly as opposed to thrice weekly dialysis. This is an interesting finding given that there are significant resource constraints in Kenya and therefore patients who are recommended to dialyse thrice weekly are dialysing twice weekly since the NHIF only covers dialysis twice a week. This raises the question as to whether twice a week dialysis is sufficient for our population considering the interdialytic weight gain is not drastically high, and in effect mortality and adverse cardiovascular outcomes may also not be so high. This also raises the question as to whether our patient population is adhering to fluid restriction and salt restriction practices more than patients in other parts of the world or whether diuretics in patients with residual renal function have an effect on this.

It is recommended that the same study be conducted using a larger sample size to assess the association between dialysate sodium concentration and interdialytic weight gain. It would also be beneficial to do a comparison study of the same outcomes of interdialytic weight gain and blood pressure control in patients on twice weekly versus thrice weekly dialysis to ascertain whether the different dialysate sodium concentrations are affected by the frequency of dialysis.

\section{Conclusion}

In summary, our study showed there was no difference in the interdialytic weight gain between the low dialysate sodium concentrations (DNa $137 \mathrm{meq} / \mathrm{l}$ ) and high dialysate sodium concentration (DNa 140 meq/l) for patients undergoing twice-weekly haemodialysis. The interdialytic weight gain in both groups was however, generally lower compared to other studies despite patients undergoing twice-weekly dialysis (as opposed to thrice-weekly). Furthermore, the blood pressures were also not different in either dialysate sodium group and this was similar to some studies. However our study did not take into account residual renal function, dietary fluid and salt intake. There is the possibility of clinical significance, despite no statistical significance for both interdialytic weight gain and blood pressures, since both were lower in the low DNa group compared to the high DNa group. 


\section{Abbreviations}

AKUH Aga Khan University Hospital

CKD Chronic Kidney Disease

DNa Dialysate Sodium Concentration

ESRD End-Stage Renal Disease

HIV Human Immunodeficiency Virus

IDWG Interdialytic Weight Gain

KDIGO Kidney Disease Improving Global Outcomes

KDOQI Kidney Disease Outcomes Quality Initiative

MAP Mean Arterial Pressure

Na Sodium

NHIF National Health Insurance Fund

PKC Parklands Kidney Centre

SLE Systemic Lupus Erythematosus

\section{Declarations}

\section{Ethics approval and consent to participate}

This study was approved by the Institutional Ethics and Review Committee of the Aga Khan University, Nairobi and the procedures were performed in accordance with the Helsinki Declaration. All the patients or their relatives were informed about the study protocol and the objectives of the study and written informed consent were obtained from each patient.

\section{Consent for publication}

Not applicable

\section{Availability of data and materials}

The datasets use for this study are available from the corresponding author on reasonable request. 
The authors declare that they have no competing interests.

\section{Funding}

This research did not receive any specific grant from any funding agencies.

\section{Author contributions}

SM implemented the research and wrote the manuscript. AS and AT supervised the research and contributed to the writing of the manuscript. JS supervised the data management and analysis and contributed to the writing of the manuscript. All authors read and approved the final manuscript.

\section{Acknowledgement}

The authors thank the staff of the Aga Khan University Hospital dialysis unit and Parklands Kidney Centre dialysis unit for their assistance in data collection.

\section{References}

1. 1. Hill NR, Fatoba ST, Oke JL, Hirst JA et al. Global prevalence of chronic kidney disease - A systematic review and meta-analysis. PLoS One [Internet]. 2016;11(7):1-18. Available from: http://dx.doi.org/10.1371/journal.pone.0158765

2. Census US. Chapter 6: Mortality. Am J Kidney Dis. 2017;69(3):S391-404.

3. Bikbov B, Purcell CA, Levey AS, Smith M et al. Global, regional, and national burden of chronic kidney disease, 1990-2017: a systematic analysis for the Global Burden of Disease Study 2017. Lancet. 2020;395(10225):709-33.

4. Couser WG, Remuzzi G, Mendis S, Tonelli M. The contribution of chronic kidney disease to the global burden of major noncommunicable diseases. Kidney Int [Internet]. 2011 Dec 2 [cited 2018 Apr 19];80(12):1258-70. Available from:

http://linkinghub.elsevier.com/retrieve/pii/S0085253815550047

5. Kwalimwa J, Mwaura J, Muiva M, Bor T et al. Barriers to access of quality renal replacement therapy in end- stage renal disease patients at the Kenyatta national hospital. IOSR J Nurs Heal Sci [Internet]. [cited 2018 Apr 19];4:2320-1940. Available from: www.iosrjournals.org

6. Oketch A. Dialysis limit puts patients' lives at risk - Daily Nation.

7. Flythe JE, Mc Causland FR. Dialysate Sodium: Rationale for Evolution over Time. Semin Dial [Internet]. 2017 [cited 2018 Apr 19];30(2):99-111. Available from:

http://www.ncbi.nlm.nih.gov/pubmed/28066913

8. Aybal Kutlugun A, Erdem Y, Okutucu S, Yorgun $\mathrm{H}$ et al. Effects of lowering dialysate sodium on flowmediated dilatation in patients with chronic kidney disease. Nephrol Dial Transplant [Internet]. 2011 Nov 1 [cited 2018 Apr 20];26(11):3678-82. Available from: https://academic.oup.com/ndt/articlelookup/doi/10.1093/ndt/gfr092 
9. Davenport A, Cox C, Thuraisingham R. The importance of dialysate sodium concentration in determining interdialytic weight gains in chronic hemodialysis patients: The PanThames Renal Audit. Int J Artif Organs. 2008;31(5):411-7.

10. Hecking M, Karaboyas A, Saran R, Sen A et al. Dialysate Sodium Concentration and the Association with Interdialytic Weight Gain, Hospitalization, and Mortality. Clin J Am Soc Nephrol. 2012;7(1):92100.

11. Beduschi GC, Telini LSR, Caramori JCT, Martin LC et al. Effect of dialysate sodium reduction on body water volume, blood pressure, and inflammatory markers in hemodialysis patients - A prospective randomized controlled study. Ren Fail. 2013;35(5):742-7.

12. Thein H, Haloob I, Marshall MR. Associations of a facility level decrease in dialysate sodium concentration with blood pressure and interdialytic weight gain. Nephrol Dial Transplant. 2007;22(9):2630-9.

13. Tangvoraphonkchai $K$, Davenport $A$. Why does the choice of dialysate sodium concentration remain controversial? Hemodial Int. 2018;22(4):435-44.

14. Ipema KJR, Kuipers J, Westerhuis R, Gaillard CAJM et al. Causes and Consequences of Interdialytic weight gain. Kidney Blood Press Res. 2016;41(5):710-20.

15. Titze J. Water-free sodium accumulation. Semin Dial. 2009;22(3):253-5.

16. Radhakrishnan RC, Varughese S, Abitha C, Shibu J et al. Effects of Individualized Dialysate Sodium Prescription in Hemodialysis - Results from a Prospective Interventional Trial. Indian J Nephrol. 2020;30(1):3-7.

17. Kayikcioglu M, Tumuklu M, Ozkahya M, Ozdogan $O$ et al. The benefit of salt restriction in the treatment of end-stage renal disease by haemodialysis. Nephrol Dial Transplant. 2009;24(3):956-62.

18. Charra B, Chazot C. Volume control, blood pressure and cardiovascular function: Lessons from hemodialysis treatment. Nephron. 2003; 93(4).

\section{Figures}




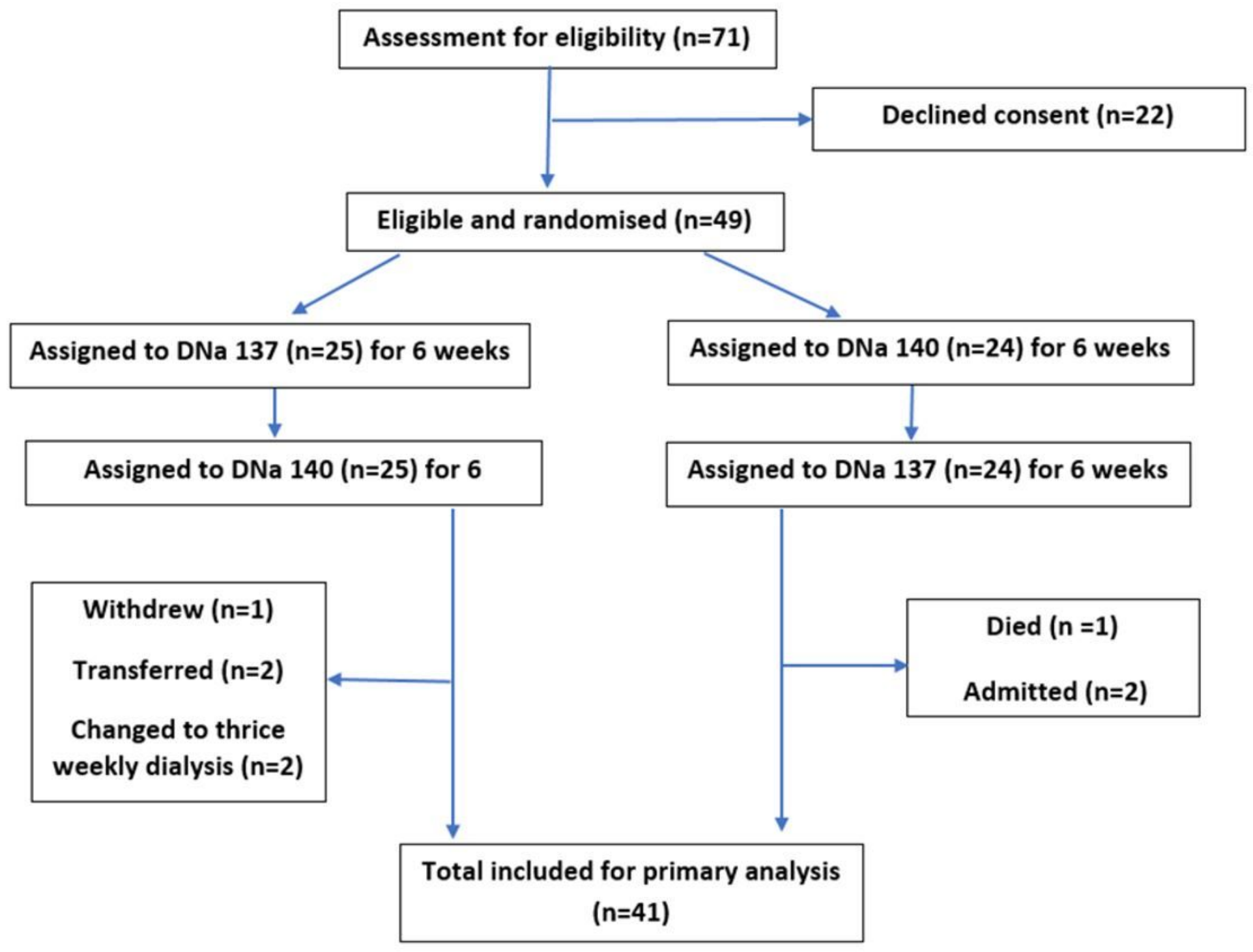

Figure 1

Participant flowchart 


\section{IDWG in the two groups}

4.5

4

3.5
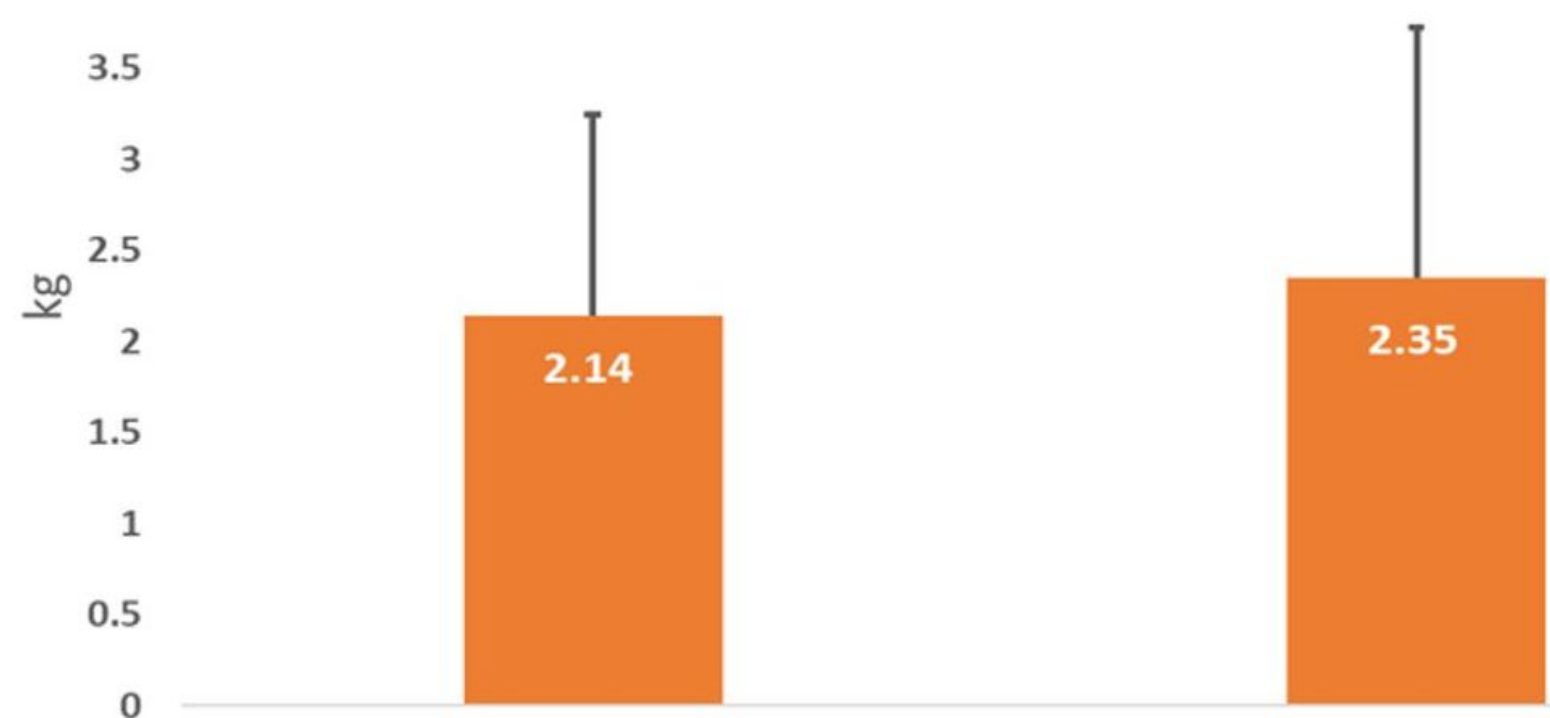

1.5

1

0.5

0

Low Na: 137 mEq/L

High Na: $140 \mathrm{mEq} / \mathrm{L}$

\section{Figure 2}

Interdialytic weight gain between DNa 137meq/I and DNa 140meq/I 